\title{
Student Worksheets with Scientific Literacy Oriented on Hydrolysis Matter by Utilizing Surrounding Materials as an Alternative Practicum in Pandemic Era
}

Gayatri Rajadewi Mega Putri*, Mitarlis

Department, Universitas Negeri Surabaya, Surabaya, 60231, Indonesia

\section{ARTICLE INFO}

Article history:

Received: 18 Jan 2021

Revised: 05 Juny 2021

Accepted: 28 Juny 2021

Published online: 24 July 2021

\section{Keywords:}

Student worksheets

Scientific literacy

Hydrolysis

Surrounding materials

Practicum

\begin{abstract}
A B S T R A C T
Student worksheets are needed to support the learning process that improves student's scientific literacy ability. This study aims to determine the feasibility of student worksheets with science literacy oriented on hydrolysis matter by utilizing surrounding materials as an alternative practicum activity in pandemic era. Research design was used the 4-D model limited to the developing stage with nine students of senior High School as research subjects. The student worksheet's feasibility is viewed from three aspects: validity, practicality, and effectiveness. The student worksheets that developed is feasible if it gets $\geq$ $61 \%$ on the validity and practicality aspects and the $\mathrm{N}$-gain is $\geq 0.3$ for the effectiveness aspect. In the validity aspect, the score was $97.20 \%$ and $97.00 \%$ for the content and construct validity criteria, on very good category. Practicality is viewed from the student response questionnaire results that get an average percentage of $97 \%$ and it's supported by the results of student's activity observations that get an average percentage of $92.84 \%$ on very practical category. The effectiveness aspect in improving science literacy ability indicated by the $\mathrm{N}$-gain score average of 0.88 , which is in the high category. Thus the student worksheets developed is feasible for use in the learning process.
\end{abstract}

\section{Introduction}

The development of science and technology that occurs affects various aspects of life, one of which is education (Ariningtyas et al., 2017). Education is one of the most important things to prepare society to meet 21 st-century demands and needs. Therefore, the government continues to make innovations and improvements in education so that human resources in Indonesia can compete with other countries. This is proved by the renewal of the curriculum that applies to education in

\footnotetext{
* Corresponding author. 
Indonesia. The 2013 curriculum was changed and revised into the 2013 revised curriculum. Revisions to the 2013 curriculum in 2017 according to the guidelines for preparing the lesson plan 2017 revised are: (1) integrating the character education in learning strengthening. The characters that are strengthened mainly include five characters, namely religious, nationalist, independent, cooperation, and integrity; (2) integrating literacy; (3) integrating 21st-century skills or termed 4C (Creative, Critical thinking, Communicative, and Collaborative); (4) Integrate HOTS (High Order Thinking Skills).

One of the 2013 curriculum revision in 2017 is integrating literacy in learning. In the 2015 PISA science framework, "Scientific Literacy is the ability to engage with science-related issues and with ideas of science, as a reflective citizen" (OECD, 2015). Scientific literacy dimensions include scientific context, scientific competence, scientific knowledge, and attitudes towards science (OECD, 2015). In particular, scientific literacy is a person's ability to master science, communicate science, and apply scientific knowledge to solve problems so he has a high attitude and sensitivity towards himself and his environment and can make decisions based on scientific considerations (Avikasari et al., 2018).

Based on PISA research from 2000 to 2018, Indonesia has a relatively low literacy ability. This low score of scientific literacy shows that in Indonesia, science learning still ignores scientific literacy. This condition requires an improvement in the science learning process in schools, considering that the quality of student's science learning outcomes is determined by the learning carried out in schools (Kusumah et al., 2020). One of the efforts to improve education in schools is to use teaching materials during the learning process. One of the teaching materials that can be used is the student worksheets. Student worksheets are expected to help students find, develop concepts, process skills, and critical thinking skills (Sanjaya, 2014).

One of the subjects in the curriculum in Indonesia is chemistry. Chemistry is scientific products obtained and developed based on experiments (Suryandari, 2016). Many students consider chemistry as a difficult subject. Based on preresearch questionnaire conducted at SMAN 1 Gedangan, as many as $80 \%$ of students considered chemistry lessons difficult to learn, and as many as 55\% of students stated that chemistry lessons were difficult to understand because the concepts were too abstract. Students think that chemistry is too abstract because, in the learning process, chemistry is not related to the phenomena that exist in everyday life. In fact, chemistry is very close to a student's daily life(Mitarlis et al., 2018).

Chemistry learning emphasizes providing direct learning experiences through the use and development of process skills and scientific attitudes, so practicum activities are essential to do. Thus, learning that takes place becomes easier to understand and meaningful for students. Based on research conducted by Ural (2016), practicum activities are effective for developing student's understanding of various aspects such as understanding scientific content to problem-solving abilities. Thus, practicum activities can be used to improve scientific literacy 
ability because scientific literacy is the ability to use scientific knowledge through the process of a scientific investigation so that students not only understand science and the environment but also can make decisions based on scientific considerations (Hermita et al., 2016).

The importance of practicum activities in chemistry learning is not in line with practice in the field. Pre-research questionnaire results show as many as $60 \%$ of students stated that learning mostly carried out learning through discussion, and as many as $55 \%$ of students said that practicum activities were rarely carried out. The implementation of practicum activities is currently being carried out increasingly rarely due to the COVID-19 pandemic, which forces learning activities to be carried out online. Many people think practicum activities are difficult to carry out in pandemic conditions, even though practicum activities can still be carried out by utilizing surrounding materials that are relatively safe for students.

COVID-19 or Coronavirus Disease 2019 is caused by the Severe Acute Respiratory Syndrome Coronavirus-2 (SARS-Cov-2) virus (Shereen et al., 2020; World Health Organization, 2019). This disease causes a pandemic with a fast transmission rate, high mortality rate and the absence of definite therapy (Susilo et al., 2020). For this reason, governments in various countries, including Indonesia, have decided to implement self-isolation and social distancing activities (Frima, 2020; Mona, 2016). This social distancing activity causes space to be very limited in various fields, including education. One of the impacts of COVID-19 pandemic is the implementation of online learning (Kemendikbud, 2020). The pandemic is still ongoing, there is no certainty when the pandemic will end, and learning can take place normally or offline (Ekantini, 2020; Lestari et al., 2020).

Learning chemistry online during the pandemic has many challenges, one of which is implementing practicum activities (Retnaningsih, 2020). This is due to constraints in providing tools and materials that students must use for practicum activities. The practicum activities can't conduct at school laboratory in the pandemic era, so it needs an alternative to conduct practicum, especially for chemistry. Chemistry is close to everyday life. All components in our life are chemical, so human life is never separated from chemistry. Therefore, chemistry learning can be designed by utilizing materials around students (Mitarlis et al., 2018).

The chemical matter studied in this study is salt hydrolysis. This is one of the chemistry material following the Annex to Permendikbud Number 21 of 2016 concerning the standard of contents of Elementary and Secondary Education Content Standards with basic competencies (KD 3.11) and (KD 4.11) (Kemendikbud, 2016). Based on research conducted by Sunartadi, et al. (2014), on the subject matter of acids, bases, and salt, a real depiction is needed, especially in everyday life around students. The use of surrounding materials not only helps the implementation of practicum activities but also shows concrete examples of the application of chemistry in daily life so that the depiction of abstract chemical concepts, especially in salt hydrolysis, can be easier for students 
to understand. The increasing understanding of students is expected to increase student's literacy ability.

Based on the reasons stated above, it takes a teaching material in the form of student worksheets that can improve student's scientific literacy. According to Wandari et al. (2018), the use of student worksheets can help students understand the concepts conveyed by the teacher. Based on the pre-research questionnaire results, 94\% of students stated that the use of student worksheets could help students understand chemistry learning easier. Student worksheets that includes practicum activities using surrounding materials is expected to make practicum activities can still be carried out even though the learning process is carried out online so that student's scientific literacy ability can be improved.

Based on the background described, there is a need to study about the development of student worksheets with scientific literacy oriented on salt hydrolysis matter by utilizing surrounding materials as an alternative practicum activity in COVID-19 pandemic era. The aims of this research are; to determine the feasibility of the student worksheets that developed based on the validity, practicality, and effectiveness of the student worksheets.

\section{Methodology}

\section{Research Design}

Design of this research is research and development refers to the 4-D development model. The 4-D development model consists of four stages namely: define, design, develop, and disseminate. This research is limited to the developing stage so that the stages of the 3-D development model as a modification of the 4-D development model used in this study shown in the Figure 1.

\section{Study Instrument}

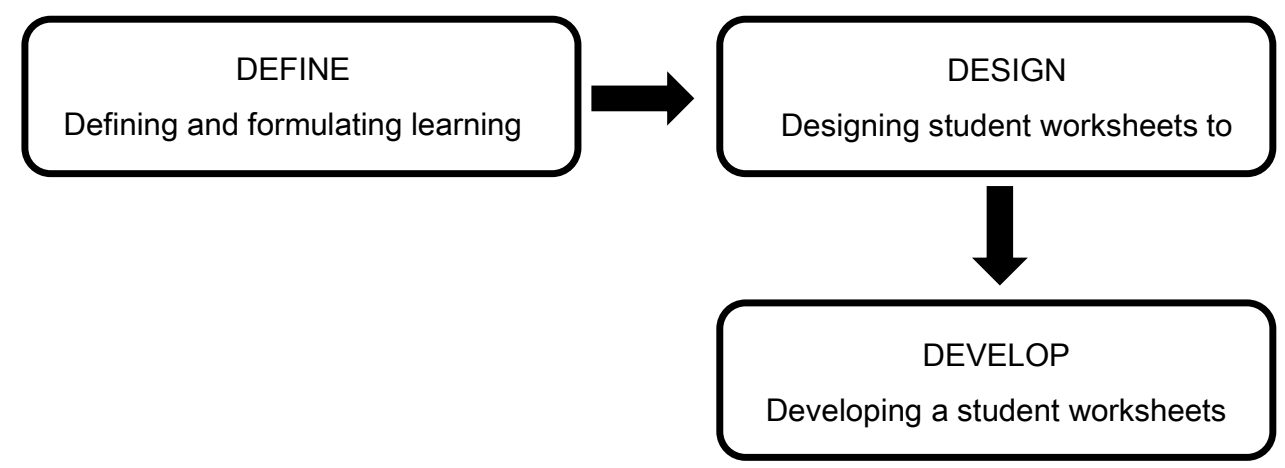

Figure 1. Design of research development of 3-D model modified from 4-D Model (Thiagarajan et al., 1974) 
This research was conducted limited trial at one of senior high school in Sidoarjo. The subjects of this study were nine students twelfth-grade Mathematics and Natural Science who had received salt hydrolysis matter.

\section{Instrument}

The instruments used in this study consist of a review sheet and validation sheet, which were used to determine the validity of the student worksheets; student response questionnaires and student activity observation sheets used to determine the practicality of student worksheets; and tests of student's scientific literacy ability used to determine the effectiveness of student worksheets.

\section{Data Analysis}

The developed student worksheets must be reviewed by an expert followed by revision, validation, and limited trials. The data were analyzed by descriptivequalitative and quantitative. During the development process, the qualitative data were analyzed by qualitative descriptive, then revised based on the expert's suggestions. Furthermore, the revised student worksheets were validated by two chemistry lecturers and one chemistry teacher.

The validity assessment uses calculations from a Likert scale with a scale of 1-5, ranging from very bad to very good (Riduwan, 2015). The data obtained from the validation results were analyzed descriptive-quantitatively through a percentage. The percentage is obtained by comparing the scores from the data collection with the score criteria score. The validity of student worksheets developed determines from the analysis of the validation sheet result using the interpretation of scores based on the criteria, as shown in Table 1.

Table 1 . Score Interpretation Criteria

\begin{tabular}{cc}
\hline Percentage (\%) & Criteria \\
\hline $0-20$ & Invalid \\
$21-40$ & Less valid \\
$41-60$ & Quite valid \\
$61-80$ & Valid \\
$81-100$ & Very valid \\
\hline
\end{tabular}

(Riduwan, 2015)

The validity of the student worksheets was viewed from the content and construct validity. The student worksheets developed can be valid if it meets the percentage results $\geq 61 \%$ in the good and very good category (Riduwan, 2015).

A limited trial is conducted after the student worksheets has been validated. Data obtained from limited trials were used to determine the practicality and effectiveness of the student worksheets being developed. The student worksheet's practicality is viewed by the result of student response questionnaire and supported by student activities observation results. Student response questionnaires are given to students who have to follow a limited trial. 
Meanwhile, observations were made by the observer by observing every aspect of each individual in each group. Data from student response questionnaires and student activities observations were then analyzed using the Guttman scale (Riduwan, 2015).

The results of calculations based on the Guttman scale criteria are converted into percentages. The student worksheets developed is said to be practically based on the Likert scale interpretation criteria, if the percentage obtained is $\geq 61 \%$. The effectiveness of student worksheets is viewed from the test scores of the student's scientific literacy ability. The pretest is carried out at the beginning of the lesson, while the posttest is carried out after the learning using the developed student worksheets has been completed. The data obtained from the pretest and posttest were analyzed using the $\mathrm{N}$-gain score equation. The amount of improvement results obtained by students is interpreted according to category as presented on Table 2. Student worksheets are said to be effective and feasible to use if the Ngain score obtained is $\geq 0.3$

Table 2. N-gain score category

\begin{tabular}{cc}
\hline Score & Category \\
\hline $\mathrm{G} \geq 0,7$ & High \\
$0,3 \leq \mathrm{G} \leq 0,7$ & Medium \\
$\mathrm{G} \leq 0,3$ & Low \\
\hline & \multicolumn{2}{c}{ (Riduwan, 2015) }
\end{tabular}

\section{Results and Discussion}

The results of the development of scientific literacy oriented student worksheets on salt hydrolysis matter using the 3-D development model can be described as follows:

\section{Define Stage}

The initial stage is the define stage which aims to define and formulate learning requirements. Several analyzes are carried out at this stage, namely front-end analysis, learner analysis, concept analysis, and task analysis. The result of this analysis is the formulation of learning objectives. The main purpose of the learning objectives is to make students have good scientific literacy ability so that they can explain scientific phenomena, evaluate and design experiments, and interpret data and evidence scientifically.

\section{Design Stage}

The design stage is carried out by arranging test criteria, selecting the media, determining the format and designing initial media. In this study, the media have chosen was a student worksheets. The reason for choosing student worksheets as a developed media is because student worksheets can increase student activity in learning. The use of student worksheets in learning can help teachers guide their 
students to find concepts through their activities (Wulandari \& Surjono, 2013). At the design stage, a student worksheets prototype was produced as a draft. There are two student worksheets which contain the subtitles of acid and alkaline salt hydrolysis. The contents of the student worksheets adjust the scientific literacy domain according to PISA (OECD, 2015). The example of the draft I student worksheets produced at the design stage according to the results of the analysis carried out in the previous stage can be seen in Figure 2.
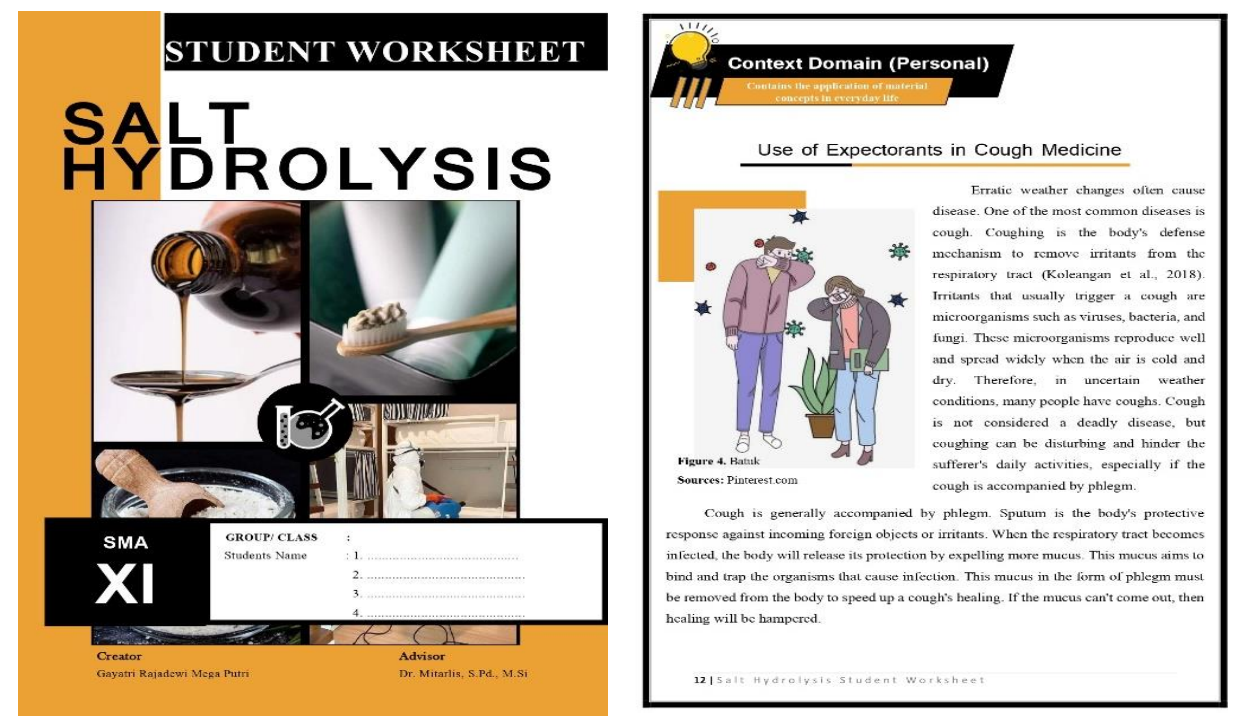

Figure 2. Example of draft I student worksheets; Cover (left); Example of scientific literacy domain in a student worksheets (right)

\section{Develop Stage}

The develop stage produces a student worksheets that already improved based on reviewers and validator's suggestions. Student worksheets that have been declared valid are then used for limited trials.

The student worksheet's initial design as a draft I produced from the design stage was carried out by chemistry lecturer using the review sheet instrument. The reviewer provides suggestions for improving the student worksheets that are developed so that the student worksheets are more appropriate and effective. The review results are used for revision so that a student worksheets are produced as draft II. An example of a revision of the student worksheets from the review results was revised as part of font that is unclear and too diverse become clearer and simpler, as shown in Figure 3.

The product of worksheets contains all domains of scientific literacy, including the domains of context, competence, knowledge and attitudes. In the context domain, is given phenomena related to the application of the chemistry concept such as salt hydrolysis in everyday life. Students must explain this phenomenon by using the competency and knowledge domains contained in the worksheets. 

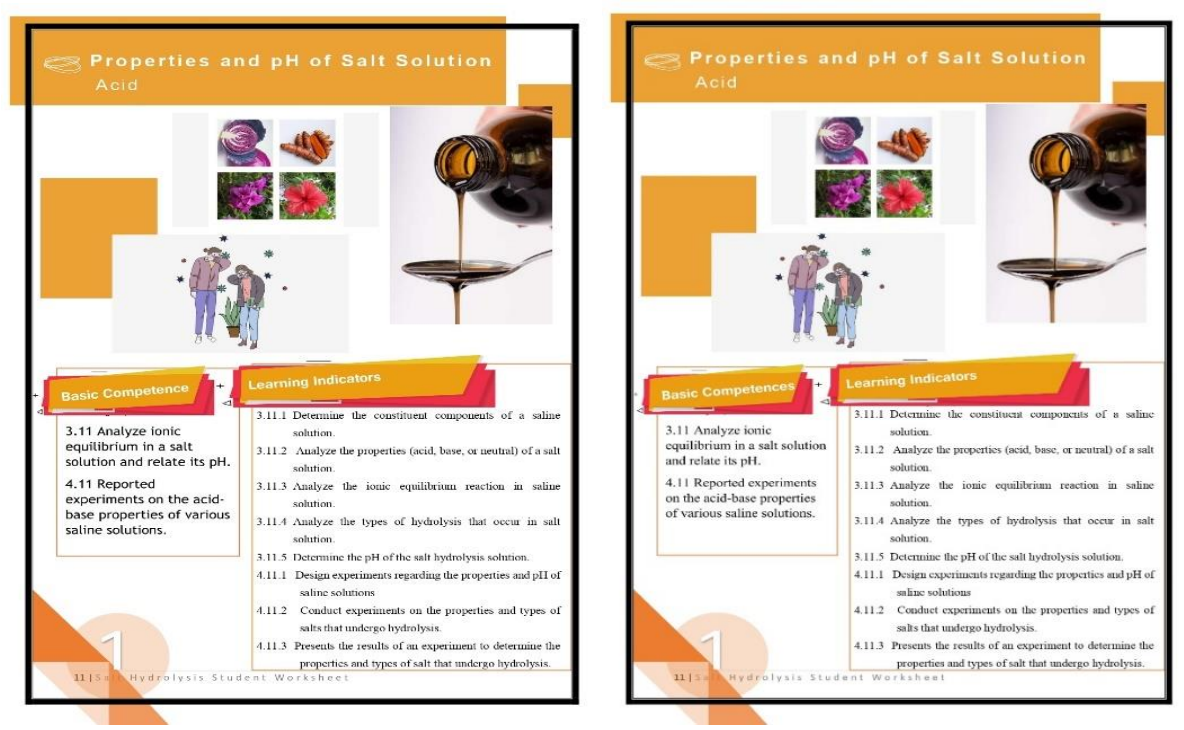

Figure 3. Example of student worksheets revision; before revision (left) and after revision (right)

In the competence domain, students are required to explain scientific phenomena, design scientific investigations related to phenomena and data interpretation is generated from these scientific investigations. The knowledge domain contains two components, namely procedural knowledge and epistemic knowledge. Procedural knowledge domain aims to guide students in producing ideas to be able to design scientific investigations. Epistemic knowledge requires students to be able to relate data obtained from scientific investigations with existing phenomena. The worksheet's attitude domain requires students to use the knowledge obtained from previous domains to make decisions based on scientific considerations (Avikasari et al., 2018). The examples of science literacy domains in the worksheets are shown in Figures 4, 5, 6, and 7.

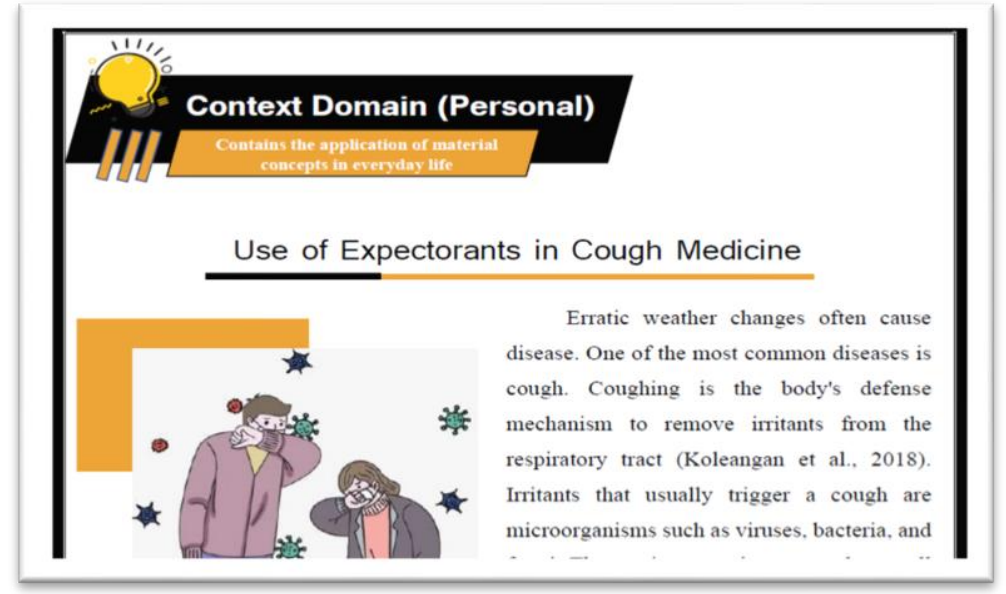

Figure 4. Example of context domain (personal) in student worksheets 


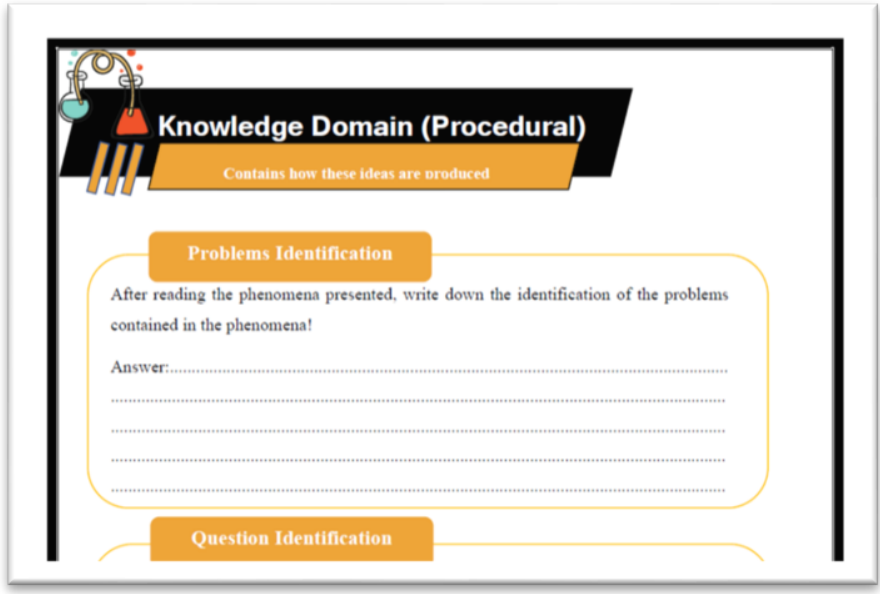

(A)

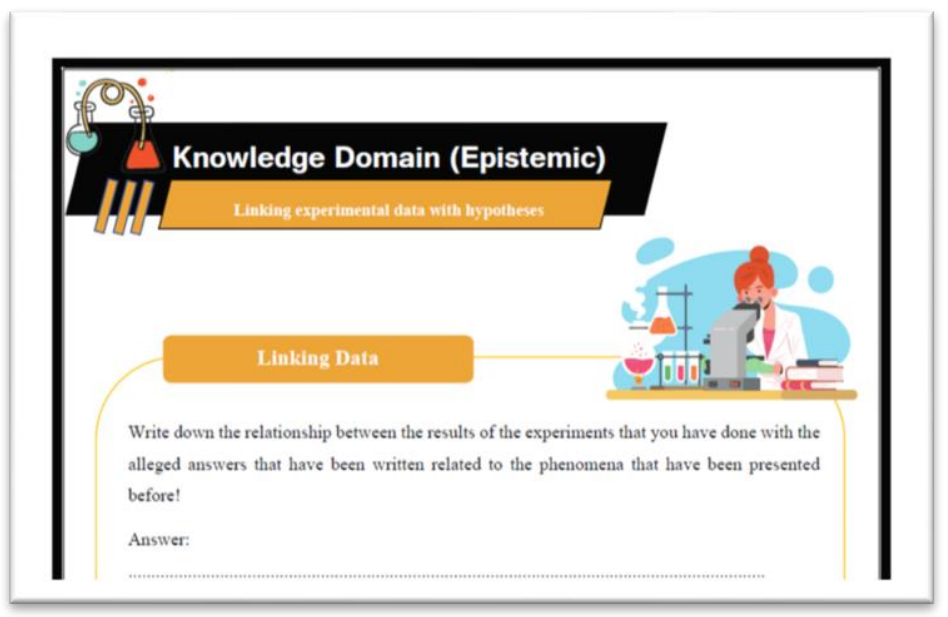

(B)

Figure 5. Example of knowledge domain procedural (A) and epistemic domain (B) in the student worksheets

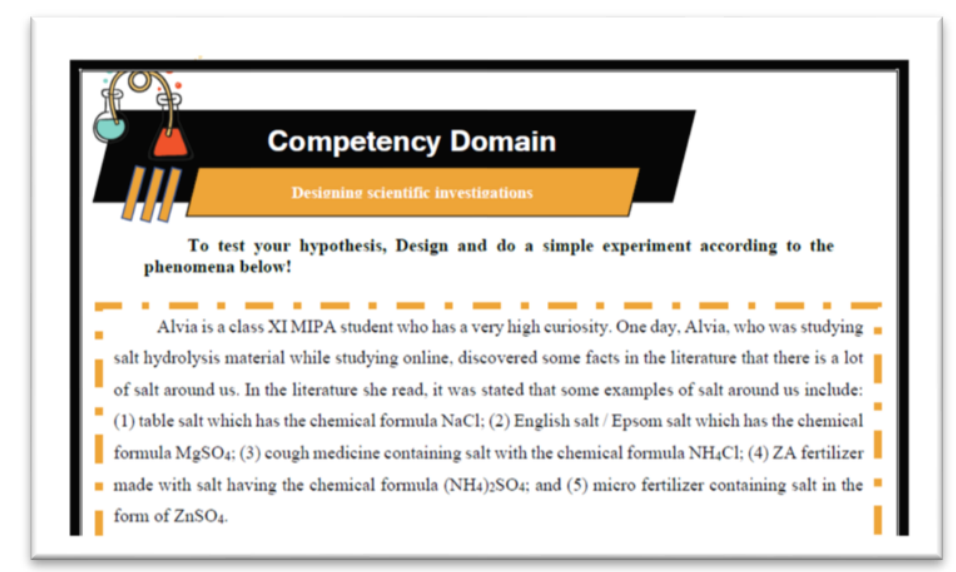

Figure 6. Example of competency domain in student worksheets 


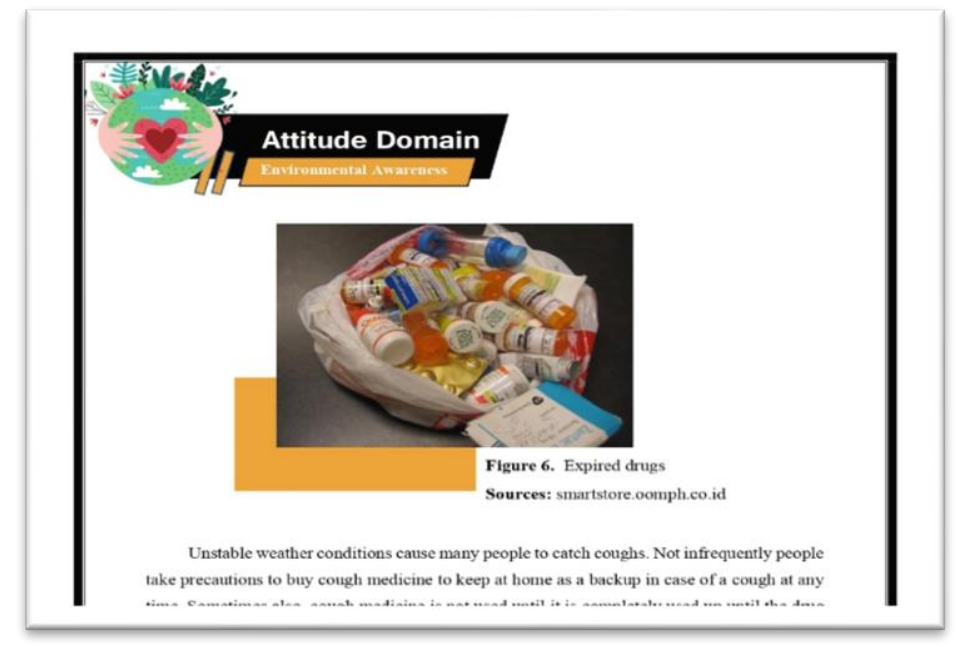

Figure. 7 Example of attitude domain in student worksheets

The presentation of scientific literacy domains contained in the worksheets is expected to support the process of students to mastery scientific literacy, especially the material of salt hydrolysis. Scientific literacy-oriented student worksheets by utilizing surrounding materials can be an alternative for carrying out practicum activities during the COVID-19 pandemic era..

\section{Validity}

The student worksheet's validity is used to see the theoretical feasibility of the student worksheets being developed. Two criteria that used to view the student worksheet's validity are content and construct validity. Student worksheets validation is done by two chemistry lecturers and one chemistry teacher. Data validation results can be seen as a diagram in Figure 8.

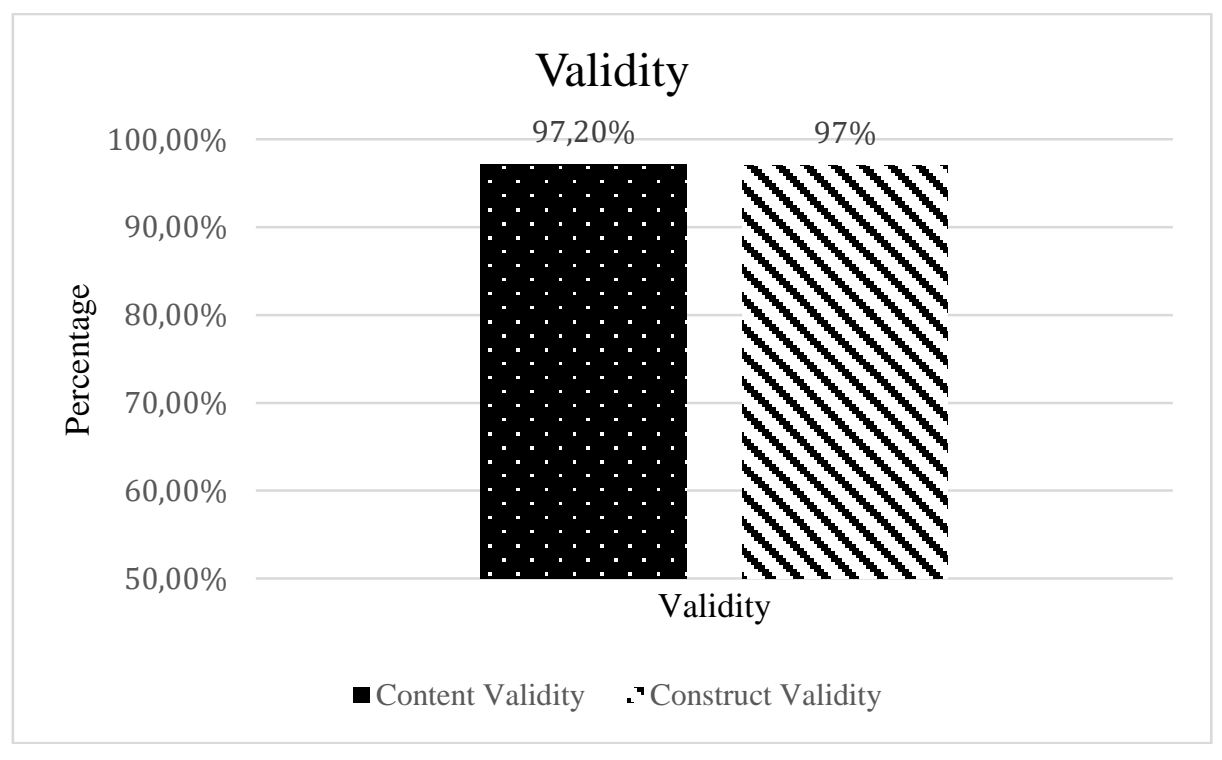

Figure 8. Content and construct validity results diagram 
The content validity is viewed from several aspects including the suitability of the material with the basic competencies in the 2013 curriculum, the suitability of phenomena and practicum activities contained in the student worksheets with the material used, and the suitability of the student worksheet's content with the scientific literacy domain. The validation results for content validity criteria get an average score of $97.20 \%$ with a very good category. This shows that the material, phenomena, practicum activities and literacy domains in the developed student worksheets are appropriate.

The construct's validity is viewed from three criteria, namely: language, presentation, and graphics. The average score obtained for construct validity is $97.00 \%$ with a very good category. Construct validity aims to support the quality of the resulting student worksheets to motivate students to learn and use more effectively. The data from the construct validity for each criterion can be seen as a diagram in Figure 9.

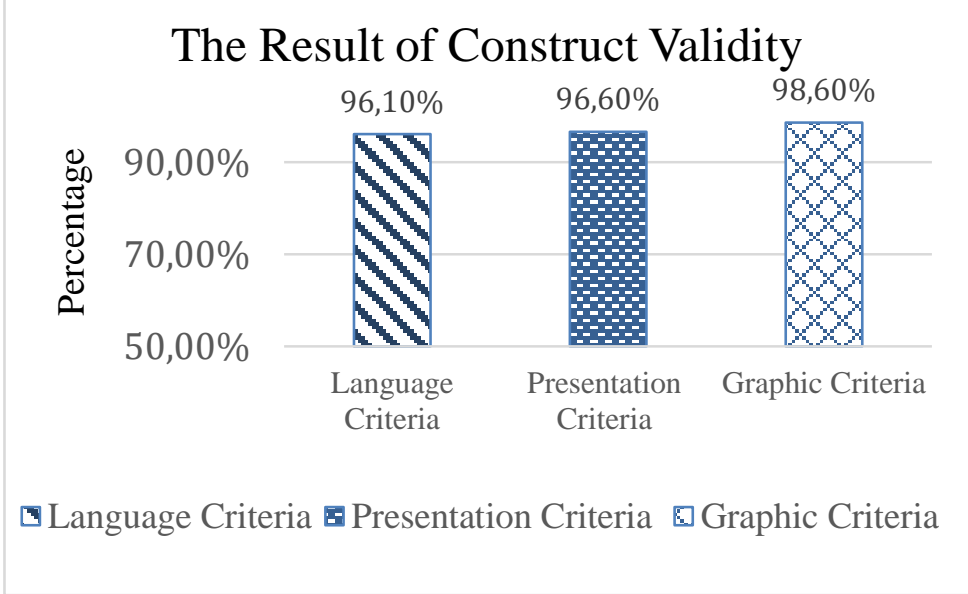

Figure 9. Construct validity results diagram

The construct validity of the language criteria got an average score of $96.10 \%$ on very good category. This shows that the student worksheets developed has used excellent and correct language and easily understood by students. The construct validity on the presentation criteria obtained an average score of $96.60 \%$ with a very good category. This means that the presentation of student worksheets is developed systematically so it doesn't confuse the students. Besides, the information presented in the student worksheets is also complete, and the student worksheets developed is also supported by pictures that help students visualize the content being studied. Then, the construct validity on the graphic criteria gets an average score of $98.60 \%$ with a very good category. This means that the student worksheets that is being developed has an attractive appearance. Thus students are expected to be motivated to learn more about the material in the student worksheets. The overall validity score for the science literacy oriented student worksheets on hydrolysis matter was $97.10 \%$ with the very good category. The results of validation by experts on both the content and construct validity criteria shown that the student worksheets developed are feasible for use for limited trials. 


\section{Practicality}

Practicality is used to determine that student worksheets can be actually used in the learning process (Ain and Mitarlis, 2020). Practicality viewed from the student response questionnaire results and supported by student activities observations result. Response questionnaires are given to students who have participated in limited trials. Based on data analysis results, scientific literacy oriented student worksheets on salt hydrolysis matter obtained an average response of $97 \%$ of students, which is very practical. More detailed data on student response questionnaires results are shown in Figure 10.

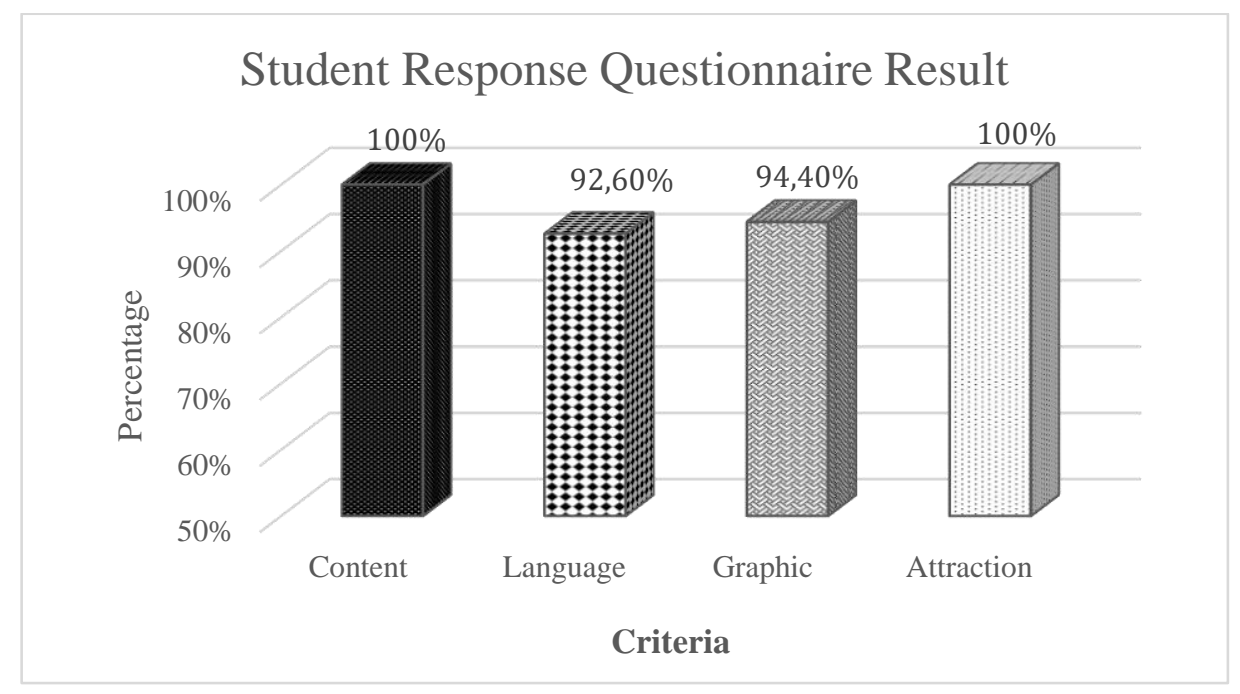

Figure 10. Student response questionnaire results

The first criteria in student response questionnaire are content. In these criteria, the student's response was $100 \%$. These results indicate that the developed student worksheet's content is appropriate, coherent, and consistent. So, it can make students learn hydrolysis material easier. The second is the language criteria which gets student's responses of $92.26 \%$. This means that the language used in the developed student worksheets is easy to understand and does not contain multiple meanings that confuse students. The third is the graphic criteria which get the response of students by $94.40 \%$. These results indicate that the student worksheet's appearance is attractive so that it does not make students bored when carrying out learning using this student worksheets. The last is the attraction criteria that get a $100 \%$ response from students. From the results obtained, it can be seen that the developed student worksheets make students motivated to learn and more interested in science so that they are more active during the learning process.

In addition to student response questionnaires, practicality is supported by the student activities observation results. Student activities show how practical the student worksheets developed can be used in learning. There were 14 activities observed by three observers. The activities observed were related to how students could actively participate in learning which was carried out using the developed 
student worksheets. The student activities observation results are shown in Figure 11. below:

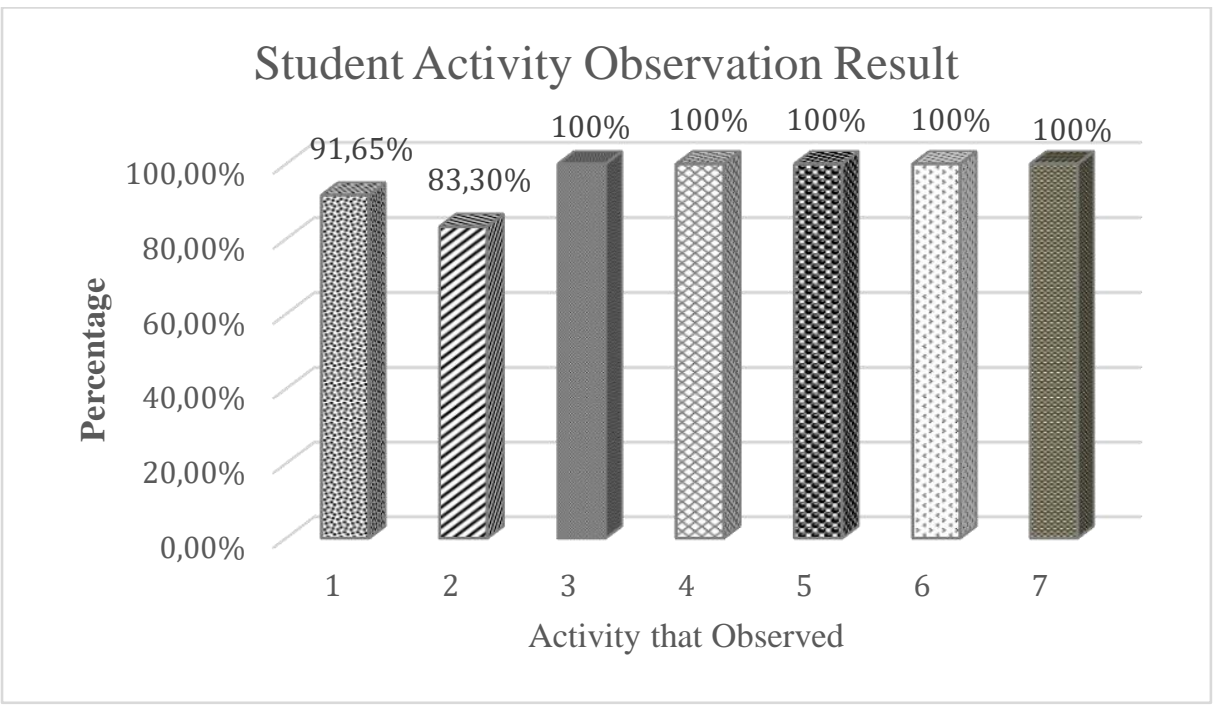

Figure 11. Student activities observation results diagram

Activity:

1. Read literature before answering

2. Design a scientific investigation

3. Do the practicum

4. Interpret experimental data

5. Conclude the experimental data

6. Relate experimental data with the phenomena

7. Communicate the answers

The diagram in Figure 11. shows that not all student activities get $100 \%$ results. In activities 1 and 2, each percentage obtained were only $91.65 \%$ and $83.30 \%$. Some students are not accustomed to reading literature first before answering questions. Some of them only answer questions according to their knowledge. Besides, some students in designing scientific investigations find it difficult to make question identification and explanatory hypotheses. This happens because they are not used to designing their scientific investigations themselves. Student's constraints were only at the first meeting. At the second meeting, students are already understood that reading literature is important to answer questions and already know how to identify questions and formulate explanatory hypotheses. The average result of student activities observation was $92.84 \%$, which is very practical. The high percentage of student response questionnaires and the student activities means that the student worksheets developed are very practical.

\section{Effectiveness}

The effectiveness of the student worksheets being developed was seen from the results of the student's pretest and posttest. The questions used in the pretest and 
posttest are questions developed based on PISA questions (OECD, 2015). The student's pretest and posttest results can be seen in Figure 12. below:

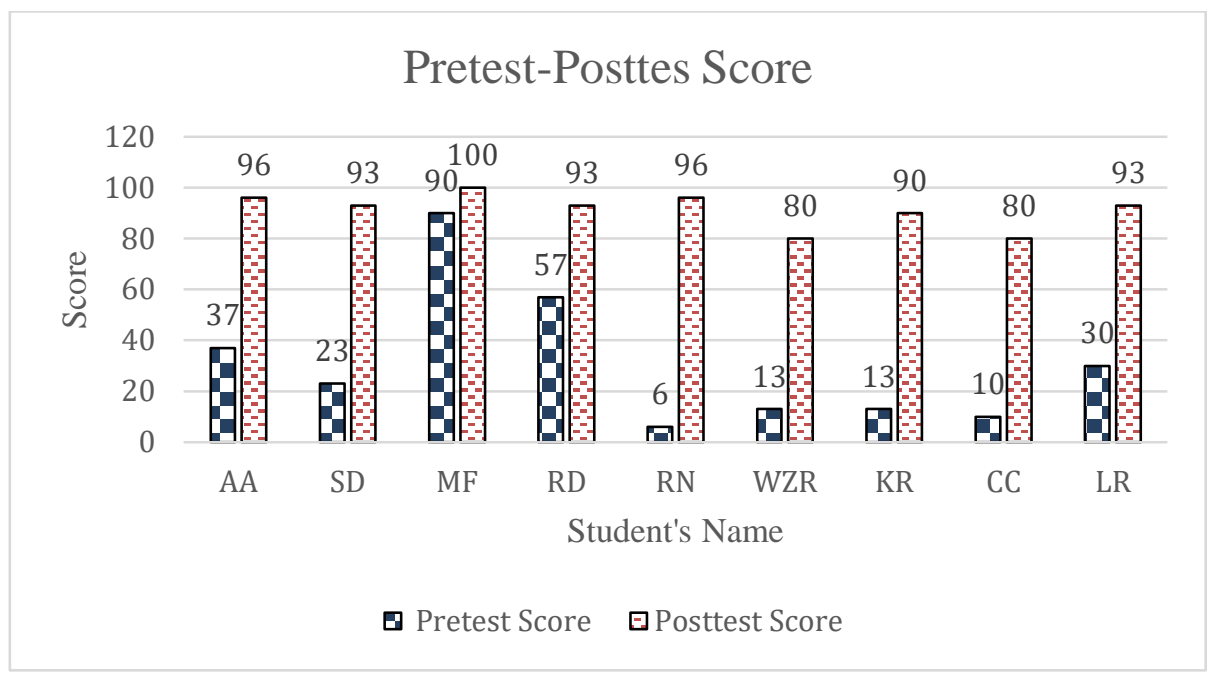

Figure 12. Student's pretest and posttest results

From the diagram shown figure 12, it can be seen that only one student completed while the others got a very low score on the pretest. This indicates that students are still very difficult to work on the scientific literacy questions given. After learning using the developed student worksheets, the student's posttest results became very high with $100 \%$ classical completeness. The pretest and posttest results obtained were then used to find the $\mathrm{N}$-gain score. Based on the data analysis carried out, the $\mathrm{N}$-gain results are shown in Figure 13.:

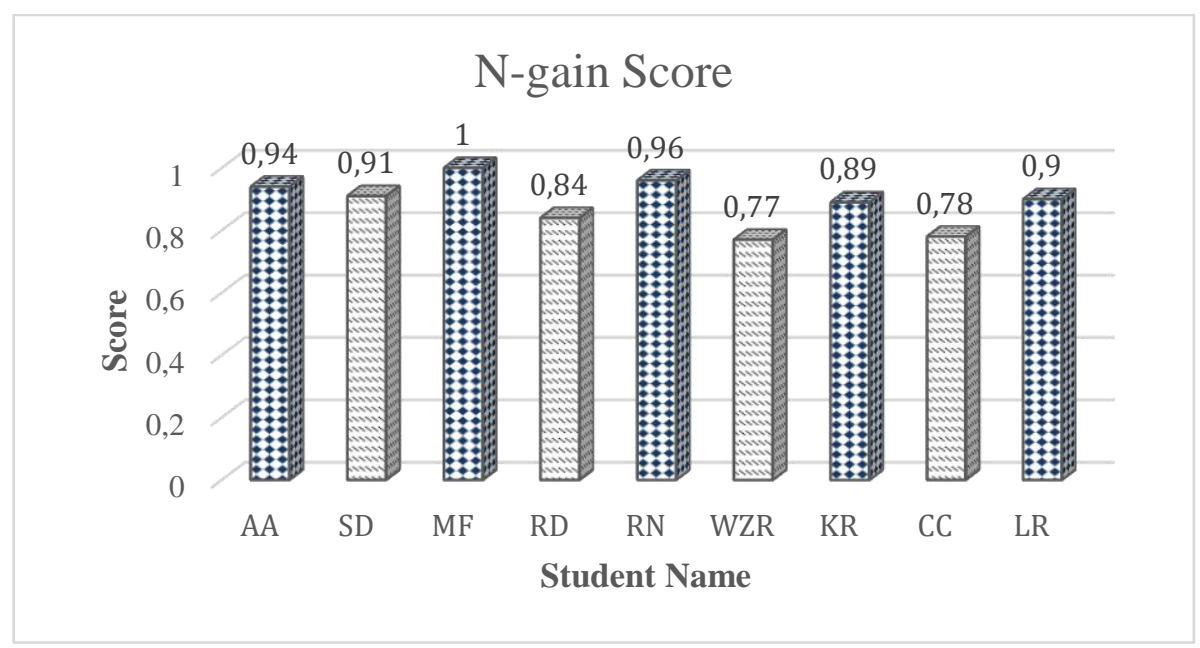

Figure 13. Diagram of the N-gain score results

Diagram in figure 13 shows that all students' N-gain score results are in the very high category with one student getting the maximum $\mathrm{N}$-gain score. The $\mathrm{N}$-gain score average of students was 0.88 . These results indicate that the scientific literacy oriented student worksheets on the salt hydrolysis material developed effectively improving student's scientific literacy. 
Student's scientific literacy ability have increased significantly because developed student worksheetss provide a more meaningful learning experience. This is because everything used in learning is related to student life or is contextual. In line with this, Gazali (2016) states that contextual problems combined with a scientific approach can make learning more meaningful. Meaningful learning is in line with the outcomes expected by scientific literacy, namely to equip students with the correct scientific concepts in-depth to be applied to daily life with real, new, and different conditions (Latip \& Permanasari, 2015).

The use of developed student worksheets makes students can directly connect the material being studied and its application in everyday life through practicum activities. The use of surrounding materials as materials used in practicum can make students see the application of hydrolysis material in everyday life and analyze its relationship with the material directly following the guidance in the student worksheets. The design of practicum activities in the developed student worksheets makes it easier for students to do practicum individually at home. Even though they are in groups, each student can still try to do practicum activities individually. Students will explore the concept more deeply by trying it themselves because learning will be more meaningful if students "work" and "experience" for themselves what they learn, not just knowing (Gazali, 2016). The concept of hydrolysis, which was previously abstract and difficult to understand for students, has become more real. Students also become more interested in science, especially chemistry, because they understand that chemistry is very close to their daily lives.

\section{Conclusion}

Based on the research that has been done, it can be concluded that the student worksheets with scientific literacy oriented on salt hydrolysis material by utilizing surrounding materials is feasible to use. The developed student worksheet's also feasible to use as an alternative practicum activity in pandemic COVID-19 era. The developed student worksheet's feasibility in terms of the validity criteria obtained from content and construct validity is in very good categories. For the criteria of practicality, the student worksheets developed got a student response with very practical category and were supported by student actitiy observation which also in the very practical category. The criteria for the student worksheet's effectiveness resulted in an increase in the $\mathrm{N}$-gain with a very high category.

\section{References}

Ariningtyas, A., Wardani, S., \& Mahatmanti, W. (2017). Efektivitas Lembar Kerja Siswa Bermuatan Etnosains Materi Hidrolisis Garam untuk Meningkatkan Literasi Sains Siswa SMA. Journal of Innovative Science Education, 6(2), 186-196.

Avikasari, A., Rukayah, R., \& Indriayu, M. (2018). The Influence of Science Literacy-Based Teaching Material Towards Science Achievement. 
International Journal of Evaluation and Research in Education (IJERE), $7(3), 182$.

Ekantini, A. (2020). Efektivitas Pembelajaran Daring pada Mata Pelajaran IPA di Masa Pandemi Covid-19: Studi Komparasi Pembelajaran Luring dan Daring pada Mata Pelajaran IPA SMP. Jurnal Pendidikan Madrasah, 5(November 2020), 187-193.

Frima, F. K. (2020). Penerapan Praktikum Jarak Jauh Pada Topik Pertumbuhan Mikroba Dalam Masa Darurat Covid-19 Di Institut Teknologi Sumatera. Jurnal Pendidikan Sains (Jps), 8(2), 102.

Gazali, R. Y. (2016). Pengembangan Bahan Ajar Matematika untuk Siswa SMP Berdasarkan Teori Belajar Ausubel. PYTHAGORAS: Jurnal Pendidikan Matematika, 11(2), 182.

Hermita, R., Suciati, \& Rinanto, Y. (2016). Pengembangan Modul Berbasis Bounded Inquiry Lab untuk Meningkatkan Literasi Sains Dimensi Konten pada Materi Sistem Pencernaan Kelas XI. Jurnal Inkuiri, 5(2), 94-107.

Kemendikbud. (2016). Permendikbud Nomor 21 Tahun 2016 Tentang Standar Proses Pendidikan dan Menengah. Jakarta: Kemendikbud.

Kemendikbud. (2020). Pembelajaran secara Daring dan Bekerja dari Rumah dalam Rangka Pencegahan Penyebaran Corona virus Disease (COVID19). https://www.kemdikbud.go.id/main/blog/2020/03/se-mendikbudpembelajaran-secara-daring-dan-bekerja-dari-rumah-untuk-mencegahpenyebaran-covid19

Kusumah, R. G. T., Walid, A., Pitaloka, S., Dewi, P. S., \& Agustriana, N. (2020). Penerapan Metode Inquiry Sebagai Usaha Untuk Meningkatkan Hasil Belajar Ipa Pada Materi Penggolongan Hewan Di Kelas Iv Sd Seluma. Jurnal Pendidikan Matematika Dan IPA, 11(1), 142-153.

Latip, A., \& Permanasari, A. (2015). Pengembangan Multimedia Pembelajaran Berbasis Literasi Sains Untuk Siswa Smp Pada Tema Teknologi. Edusains, 7(2), 160-171.

Lestari, M. I., Barat, J., Tengah, J., \& Timur, J. (2020). Analisis Dampak Sentimen Masyarakat Selama Pandemi Covid-19 Terhadap Kurs Rupiah (Studi Kasus Pandemi Covid-19 di Indonesia). Jurnal EMBA: Jurnal Riset Ekonomi, Manajemen, Bisnis Dan Akuntansi, 9(1), 1-14.

Mitarlis, Azizah, U., \& Yonatha, B. (2018). Pemanfaatan Indikator Alam dalam Mewujudkan Pembelajaran Kimia. Jurnal Penelitian Pendidikan IPA, $3(1), 1-7$.

Mona, N. (2016). Mekanisme Contagion dalam Jaringan Sosial. Depok: Universitas Indonesia.

OECD. (2015). PISA 2015: Assessment and Analytical Framework: Science, Reading, Mathematic and Financial Literacy. OECD Publishing.

Retnaningsih, R. (2020). E-Learning system sebuah solusi pragmatis program vokasional semasa pandemi COVID-19. Taman Vokasi, 8(1), 28.

Riduwan. (2015). Skala Pengukuran Variabel-Variabel. Bandung: Alfabeta.

Sanjaya, W. (2014). Strategi Pembelajaran. Pertama. Jakarta: Kencana Prenada Media Group.

Shereen, M. A., Khan, S., Kazmi, A., Bashir, N., \& Siddique, R. (2020). COVID19 infection: Origin, transmission, and characteristics of human coronaviruses. Journal of Advanced Research, 24, 91-98. 
https://doi.org/10.1016/j.jare.2020.03.005

Sunartadi, S., Sukardjo, J., \& Nurhayati, N. (2014). Studi Komparasi Pembelajaran Number Head Together (Nht) Dengan Menggunakan Media Demonstrasi Dan Percobaan Pada Pokok Bahasan Asam, Basa Dan Garam Terhadap Prestasi Belajar Siswa Kelas Vii Smp Negeri 2 Sawit Boyolali Tahun Pelajaran 2012/2013. Jurnal Pendidikan Kimia, 3(4), 24-30.

Suryandari, E. T. (2016). Performance Assessment Sebagai Instrumen Penilaian Untuk Meningkatkan Ketrampulan Proses Pada Praktikum Kimia Dasar Di Tadris Kimia. Phenomenon: Jurnal Pendidikan MIPA, 3(2), 19.

Susilo, A., Rumende, C. M., Pitoyo, C. W., Santoso, W. D., Yulianti, M., Herikurniawan, H., Sinto, R., Singh, G., Nainggolan, L., Nelwan, E. J., Chen, L. K., Widhani, A., Wijaya, E., Wicaksana, B., Maksum, M., Annisa, F., Jasirwan, C. O. M., \& Yunihastuti, E. (2020). Coronavirus Disease 2019: Tinjauan Literatur Terkini. Jurnal Penyakit Dalam Indonesia, 7(1), 45.

Thiagarajan, S., Semmel, D. S., \& Semmel, M. . (1974). Membangun Literasi Sains Peserta Didik. Indiana: Indiana University.

Ural, E. (2016). The Effect of Guided-Inquiry Laboratory Experiments on Science Education Students' Chemistry Laboratory Attitudes, Anxiety and Achievement. Journal of Education and Training Studies, 4(4), 217-227.

Wandari, A., Kamid, K., \& Maison, M. (2018). Pengembangan Lembar Kerja Peserta Didik (LKPD) pada Materi Geometri berbasis Budaya Jambi untuk Meningkatkan Kreativitas Siswa. Edumatika: Jurnal Riset Pendidikan Matematika, 1(2), 47.

World Health Organization. (2019). Coronavirus. Retrieved from World Health Organization. https://www.who.int/health-topics/coronavirus\#tab=tab_1

Wulandari, B., \& Surjono, H. D. (2013). Pengaruh problem-based learning terhadap hasil belajar ditinjau dari motivasi belajar PLC di SMK. Jurnal Pendidikan Vokasi, 3(2), 178-191.

How to cite this article:

Putri, G. R.M., \& Mitarlis. (2021). Student Worksheets with Scientific Literacy Oriented on Hydrolysis Matter by Utilizing Surrounding Materials as an Alternative Practicum in Pandemic Era. Journal of Educational Sciences, $5(3), 542-558$. 